\title{
ОЦЕНКА МУТАГЕННОЙ АКТИВНОСТИ НОВОГО АНТИТРОМБОТИЧЕСКОГО ЛЕКАРСТВЕННОГО СРЕДСТВА
}

\section{Г.Л. Снигур ${ }^{1}$, Д.А. Кавалерова', С.С. Сурин ${ }^{1}$, А.Ф. Кучерявенко²}

\author{
${ }^{1}$ Кафедра биологии, ${ }^{2}$ кафедра фармакологии и биоинформатики \\ ФГБОУ ВО ВолгГМУ Минздрава России \\ 400131 Россия, г. Волгоград, площадь Павших Борцов 1.
}

DOI: 10.19163/MedChemRussia2021-2021-493

E-mail:dareznikova@yandex.ru

Целью работы являлось определение мутагенного потенциала нового антитромботического лекарственного средства с комбинированным механизмом действия - блокатора $\mathrm{P}_{2} \mathrm{Y}_{12}$ рецептора и ингибитора синтеза тромбоксана $\mathrm{A}_{2}$, на основе производного гидробромид9-[2-(3,4-дигидроксифенил)-2оксоэтил]-2,3-дигидроимидазо[1,2-a]бензимидазола в тестах invitro и invivo.

В тесте на индукцию генных мутаций (тест Эймса) изучались ФС и ГЛФ в концентрациях: 2,5 мг/мл, 1,25 мг/мл, 0,625 мг/мл, 0,3125 мг/мл, 0,15625 мг/ мл и 0,078125 мг/мл. Для выявления мутагенного потенциала фракцией S9+/ S9- печени были использованы S.typhimurium TA98, TA100, TA1535, TA1537 и E.coli WP2 uvrA + WP2 [рKM101] для регистрации мутаций по типу замены пар оснований и сдвига рамки считывания [2]. Цитогенетическое исследование на индукцию хромосомных аберраций в клетках костного мозга мышей было проведено в двух сериях: однократное введение ФС и ГЛФ (самцы в терапевтической - 23 мг/кг, и субтоксической дозах - 204 мг/кг) и курсовое введение ФС и ГЛФ (самцы и самки в терапевтической дозе - 23 мг/кг). В качестве положительного контроля вводился мутаген (циклофосфамид - 20 мг/кг), в качестве отрицательного контроля вводилась дистиллированная вода [1].

В тесте Эймса под действием ФС и ГЛФ по сравнению с негативным контролем не происходило статистически значимого увеличения ревертантных колоний. В цитогенетическом исследовании при введении ФС и ГЛФ в терапевтической и субтоксической дозах не выявлялось значимого увеличения уровня хромосомных аберраций. Результаты исследования по влиянию ФС и ГЛФ на индукцию генных мутаций в тесте Эймса и хромосомных аберраций в цитогенетическом тесте могут свидетельствовать об отсутствии мутагенной активности у изучаемого нового антитромботического средства.

\section{Литература:}

[1]. А.Н.Миронов, руководство по проведению доклинических исследований лекарственных средств. Часть первая-М: Гриф и К, 2012. -С.80-93.

[2]. Ames MPFTM Penta I Xenometrix, Швейцария, Инструкция по применению теста Эймса в микропланшетном формате версия набора с полутвердыми стоками штаммов. Версия 4.5_S, 2012, 37 с. 